\title{
MEDICAL TABLETS PARACETAMOL AND MERTRONIDAZOLE AFFECTS WHEAT SEED GERMINATION AND SEEDLINGS GROWTH AS PLANT GROWTH REGULATORS
}

\author{
Ahmed S. Khalaf, FAthi A. OMer and Khalil A. KHalil \\ Dept. of Field Crops, College of Agricultural engineering science , University of Duhok, \\ Kurdistan Region -Iraq
}

(Accepted for Publication: October 21, 2019)

\begin{abstract}
Triazole derivatives are regularly used as systemic fungicides for seed dressing or as plant growth regulator, but it can cause numerous changes in plant morphological and physiological characteristics. An experiment included the local Iraqi bread wheat variety Tammuz-2 and the introduced Turkish ones Adana-99 were exposed to two concentrations $(500$ and $1000 \mathrm{ppm})$ of the antibiotic medicinal tablets paracetamol and metronidazole, to illustrate the biological activity in terms of seeds germination and early seedlings growth traits; as they are structurally resemble the well-known azole fungicides and growth retardant derivatives. The results obviously revealed that these drugs exhibited growth regulatory activity in terms of their toxic effects in reducing of germination \% from $84.5 \%$ to $69.75 \%$ for Tammuz-2 with paracetamol at $1000 \mathrm{ppm}$, and from $84.50 \%$ to $76.00 \%$ with metronidazole at the same concentration. Similarly the germination\% of Adana $\mathbf{- 9 9}$ was also dropped from $91.5 \%$ to $77 \%$ and $82.5 \%$ for paracetamol and metronidazole at $1000 \mathrm{ppm}$, respectively, this reduction in germination $\%$ was accompanied with increment in abnormal seedlings\%. The deleterious impact on Adana-99 shoot length was exaggerated with metronidazole at $1000 \mathrm{ppm}$ which recorded $(5.75 \mathrm{~cm})$ in comparison to control $(10.11 \mathrm{~cm})$. Concerning with the length of the longest rootlet, drastic reduction was noticed for both varieties with metronidazole at both concentrations 500 and $1000 \mathrm{ppm}$, but the lowest was $1.47 \mathrm{~cm}$ at $1000 \mathrm{ppm}$ for metronidazole in comparison to the control $11.21 \mathrm{~cm}$ for Tammuz-2 variety. The effect of drugs on number of rootlets resembled rootlets length as it was reduced by metronidazole, whereas the highest concentration 1000ppm only significantly reduced seedlings fresh weight. Although there was discrepancy in seedlings dry weight as metronidazole particularly with high concentration caused drastic suppression in rootlets growth, but it resulted in higher dry weight, the interpretation for such ambiguity was that the seeds were not removed from the seedlings and it was contributed in whole seedlings weight and could be also due to the better food reserved in the germinated seeds. It was worth to declare that paracetamol treated seeds colored dark black, which was attributed to the tyrosinase enzyme activity present in seeds pericarp which oxidize phenol into quinines and subsequently converted to dark colored melanin by polymerization and interaction with protein. The results ascertained the side effect of these drugs as they possess regulatory behavior; therefore awareness required utilizing such pharmaceutical compounds to avoid unanticipated risk of soil contamination and agricultural ecosystems pollution.
\end{abstract}

KEY Words: Wheat, Paracetamol, Mertronidazole, Seed germination, Growth regulators https://doi.org/10.26682/cajuod.2020.22.2.6

\section{INTRODUCTION}

Triazole derivatives are regularly used as systemic fungicides for crop seed dressing to produce uniform and healthy seedlings, ultimately to maximize the yield; or as plant growth regulator, but it can alter plant morphological and physiological characteristics. Jung, et al., 1985, proved growth retardation of triazoles growth regulators in barley, rice and oil seed rape seedlings, and the action of this retardant antagonized by gibberellin $\mathrm{A}_{3}$ and entkaurenoic acid; its main biochemical action was to block the reactions that lead from ent-kaurene to ent-kaurenoic acid in the course of gibberellin biosynthesis. Furthermore, Lurssen, 1987, reported that enantiomers of uniconazol, paclobutrazol and triapenthenol selectively act as 
plant growth regulators or fungicides; Lurssen and Reiser; 1987, mentioned that the main influence of triapenthenol is an inhibition of shoot growth, but root growth was not inhibited at normal dosages. Similarly, Koller, 1987, stated that the azole fungicide triadimenol exhibited pronounced plant growth regulator activity, mainly resulting in growth retardation. Hof, et al., 1987, reported that dressing wheat seeds with the fungicide sibutol initially stimulate the net biosynthesis of $\alpha$-amylases during germination, but later affected the growth of wheat coleoptile and roots differently. The results of Khalaf, 1989, were in consistent with foregoing investigators as he noticed increment in the number of abnormal wheat seedlings due to application of triadimenol fuberidazole systemic fungicide, inhibition of shoot length, but increment in the number of rootlets, particularly with bitertanol fuberidazole which resulted in retardation of root growth.

The plant growth regulating properties of triazole a fungicide has been illustrated by Montfort, et al, 1996; reduction of wheat coleoptile length was observed. Whereas Smiley, et al., 1996, reported that the azole fungicide imazalil had either no effect or inhibited emergence and stand establishment of wheat in the field. The toxic behavior of metronidazole drug on maize was also reported by Viccini, et al., 1997. Enhancement in wheat seedlings growth rate under temperature stress conditions was recorded due to paclobutrazol treatment, assuming that the stress protection contributes to some extent to the enhancement activity of the free-radical scavenging systems (Berova, et al., 2002). Such regulator activity was confirmed by Gortz, et al., 2008, for the triazole fungicide triadimenol on barley treated seeds.

The azoles drugs are gaining increasing popularity for their effectiveness against fungal rhino-sinusitis, which is a vital component of the fungal cell membrane. (Khattar and Hathiram, 2009). Also, An, et al, 2009 referred to the ecotoxicological effects of paracetamol on wheat seed germination and seedling development (roots were most sensitive sites of the plants to paracetamol) and the effect depends on concentrations. The cytotoxic effects of triazole fungicides have been proved by Bulbul and Ozhan, 2012, who recommend awareness of toxic effects of triazole fungicides which was identified as cytotoxic for human and environment health.

Kumar, et al., 2016, found higher seedlings dry weight of onion treated with paclobutrazol retardant, they attributed to the better food reserve in seed, although seed germination was not significantly affected. Soumya et al., 2017 recorded the growth regulation activity for the triazole family. Attarzadeh, et al., 2018, who referred to an increase in soybean shoot dry weight due to paclobutrazol growth regulator application under cold stress; their interpretation was that it increases the tolerance of soybean to cold tension. On the other hand, Kumar et al., 2019 recorded low wheat germination due to Tebuconazole fungicide. Accordingly, this study was conducted to ascertain whether these medicinal drugs possess any regulatory behavior for wheat germination and early seedlings growth as they are structurally resemble to wellknown azole derivatives, to avoid unanticipated risk of soil contamination with pharmaceutical compounds and agricultural ecosystems pollution.

\section{MATERIAL AND METHODS}

Freshly harvested wheat of the season 2018 for the local variety bread wheat, Tammuz-2, (Iraqi -released and registered by Iraqi atomic energy commission. 1992, pedigree- Mexipak /Saberbeg) and the Turkish variety Adana-99, (pedigree PFAU/SERI-82//(SIB)BOBWHITE (2400)(2850), were collected from Agricultural Researches Directorate, Duhok governorate , Iraqi Kurdistan Region.

Pure and homogenized sized seeds larger than $3.35 \mathrm{~mm}$, were subjected to ISTA rules (2013) of standard germination test by germinating four replicates of 50 seeds, each 25 seeds per Petri plate on a single layer filter paper watered by $8 \mathrm{ml}$ distilled water as control treatment, and with $8 \mathrm{ml}$ of aqueous solution of the two concentrations 500 and $1000 \mathrm{ppm}$ of the two medicinal antibiotic drug tablets paracetamol (N-acetyl-para-aminophenol) and metronidazole (2-methyl-5-nitroimidazole-1ethanol).

Single tablet of $500 \mathrm{mg}$ for each drug was finely ground by laboratory mill and dissolved in one liter distilled water to prepare 500ppm, and two tablets of $500 \mathrm{mg}$ for each drug were 
dissolved in one liter distilled water for preparation of $1000 \mathrm{ppm}$ concentration. As ppm = mass solute $(\mathrm{mg}) /$ volume solvent $(\mathrm{L})$. Then Petri plates with the germinated seeds were placed in plastic box with lid to avoid sample dryness.

The germinated seeds were incubated in germinator fixed on $20^{\circ} \mathrm{C}$ for eight days, after that seedlings were evaluated and sorted into normal germinated seedlings $\%$ (germination $\%$ ), abnormal seedlings \%, mean of ten randomly selected seedlings were measured for shoot length $\mathrm{cm}$, longest rootlet length $\mathrm{cm}$, number of rootlets per seedling, and seedlings fresh weight and dry weight.

Data were statistically analyzed using SAS, 2003.Program version, 9.1, and Duncan's multiple range test was used for verifications of means at 0.05 level of significant.

\section{RESULTS AND DISCUSSION}

Wheat varieties varied significantly in seed germination percentage, Adana-99 recorded higher germination\% than Tammuz-2, this was accompanied by higher seedlings abnormalities in Tazmmuz-2 variety. (table 1 and 2). Concerning with the influence of drug tablets solutions, Metronidazole resulted in significantly higher germination \% than paracetamol treatment regardless of seedlings abnormalities as they were not significant differences between the two drugs.

As the drugs concentrations raised, seed germination $\%$ impaired similarly with both concentrations 500 and $1000 \mathrm{ppm}$ in comparison to the control treatment and was accompanied by parallel increment of seedlings abnormalities.

Table (1): Influence of aqueous medicinal tablets of paracetamol and metronidazole on seed germination \% of two bread wheat varieties.

\begin{tabular}{llllll}
\hline \multirow{2}{*}{$\begin{array}{c}\text { Varieties } \\
\text { tablets }\end{array}$} & 0.00 & \multicolumn{3}{c}{ Concentrations } \\
& Paracetamol & $84.50 \mathrm{ab}$ & $66.50 \mathrm{~d}$ & $69.75 \mathrm{~cd}$ & $73.58 \mathrm{~b}$ \\
Tammuz-2 & Metronidazole & $84.50 \mathrm{ab}$ & $78.00 \mathrm{bc}$ & $76.00 \mathrm{bc}$ & $79.50 \mathrm{ab}$ \\
& Paracetamol & $91.50 \mathrm{a}$ & $75.50 \mathrm{bc}$ & $77.00 \mathrm{bc}$ & $81.33 \mathrm{a}$ \\
Adana-99 & Metronidazole & $91.50 \mathrm{a}$ & $80.50 \mathrm{~b}$ & $82.50 \mathrm{~b}$ & $84.83 \mathrm{a}$ \\
Tammuz-2 & & $84.50 \mathrm{~b}$ & $72.25 \mathrm{~d}$ & $72.87 \mathrm{~d}$ & $76.54 \mathrm{~b}$ \\
Adana-99 & & $91.50 \mathrm{a}$ & $78.00 \mathrm{~cd}$ & $79.75 \mathrm{bc}$ & $83.08 \mathrm{a}$ \\
Paracetamol & & $88.00 \mathrm{a}$ & $71.00 \mathrm{c}$ & $73.37 \mathrm{bc}$ & $77.45 \mathrm{~b}$ \\
Metronidazole & & $88.00 \mathrm{a}$ & $79.25 \mathrm{~b}$ & $79.25 \mathrm{~b}$ & $82.16 \mathrm{a}$ \\
Means & & $88.00 \mathrm{a}$ & $75.12 \mathrm{~b}$ & $76.31 \mathrm{~b}$ & \\
\hline
\end{tabular}

* Means of each factor or their interaction shared similar letters are not significantly different at $5 \%$ level according to Duncan test.

All treatment combinations interaction were significant and the second order interaction were significantly different for both germination\% and abnormal seedlings \%, the highest germination \% was for both varieties with the control (water treatment), $84.5 \%$ and $91.5 \%$ for
Tammuz-2 and Adana-99 varieties respectively; while the lowest were for Tammuz-2 variety with 500 and 1000ppm of paracetamol treatments, which were accompanied with highest seedlings corresponded treatments.

Table (2): Influence of aqueous medicinal tablets of paracetamol and metronidazole on abnormal seedlings $\%$ of two bread wheat varieties.

\begin{tabular}{llllll}
\hline Varieties & \multicolumn{1}{c}{$\begin{array}{c}\text { Medicinal } \\
\text { tablets }\end{array}$} & 0.00 & $500 \mathrm{ppm}$ & $1000 \mathrm{ppm}$ & Means \\
\cline { 2 - 5 } & & $9.50 \mathrm{a}$ & $11.50 \mathrm{~b}$ & $19.00 \mathrm{a}$ & $13.33 \mathrm{a}$ \\
Tammuz-2 & Paracetamol & $9.50 \mathrm{a}$ & $10.00 \mathrm{~b}$ & $13.00 \mathrm{~b}$ & $10.83 \mathrm{ab}$ \\
\hline
\end{tabular}




\begin{tabular}{llllll}
\hline & Paracetamol & $3.00 \mathrm{c}$ & $12.50 \mathrm{~b}$ & $9.50 \mathrm{~b}$ & $8.33 \mathrm{~b}$ \\
Adana-99 & Metronidazole & $3.00 \mathrm{c}$ & $10.50 \mathrm{~b}$ & $9.25 \mathrm{~b}$ & $7.58 \mathrm{~b}$ \\
\hline Tammuz-2 & & $9.50 \mathrm{~b}$ & $14.50 \mathrm{a}$ & $12.25 \mathrm{ab}$ & $12.08 \mathrm{a}$ \\
Adana-99 & $3.00 \mathrm{c}$ & $11.50 \mathrm{ab}$ & $9.37 \mathrm{~b}$ & $7.95 \mathrm{~b}$ \\
\hline Paracetamol & $6.25 \mathrm{c}$ & $15.75 \mathrm{a}$ & $10.50 \mathrm{bc}$ & $10.83 \mathrm{a}$ \\
Metronidazole & $6.25 \mathrm{c}$ & $10.25 \mathrm{bc}$ & $11.12 \mathrm{~b}$ & $9.20 \mathrm{a}$ \\
\hline Means & $6.25 \mathrm{~b}$ & $12.06 \mathrm{a}$ & $11.74 \mathrm{a}$ & \\
\hline
\end{tabular}

* Means of each factor or their interaction shared similar letters are not significantly different at $5 \%$ level according to Duncan test.

The values displayed in table (3) were eight days old seedlings plumule length, revealed to no significant differences between wheat varieties, whereas significant differences were obvious for drugs and their concentrations; as metronidazole reduced plumule length particularly at the concentration 1000ppm. All treatments interactions were significantly affected this trait, regarding triple interaction the most deleterious impact was for the variety Adana-99 with metronidazole at 1000ppm which gave $5.73 \mathrm{~cm}$ plumule length.

Table (3): Influence of aqueous medicinal tablets of paracetamol and metronidazole on shoot length $(\mathrm{cm})$ of two bread wheat varieties.

\begin{tabular}{|c|c|c|c|c|c|}
\hline \multirow[t]{2}{*}{ Varieties } & \multirow{2}{*}{$\begin{array}{c}\text { Medicinal } \\
\text { tablets }\end{array}$} & \multicolumn{3}{|c|}{ Concentrations } & \multirow[t]{2}{*}{ Means } \\
\hline & & 0.00 & 500 ppm & 1000 ppm & \\
\hline \multirow{3}{*}{ Tammuz-2 } & Paracetamol & $10.14 a$ & $10.61 \mathrm{a}$ & $9.80 \mathrm{ab}$ & $10.19 a$ \\
\hline & Metronidazole & $10.14 \mathrm{a}$ & $9.65 a b$ & $5.78 c$ & $8.52 b$ \\
\hline & Paracetamol & $10.07 a$ & $10.32 a$ & $9.68 \mathrm{ab}$ & $10.02 a$ \\
\hline Adana-99 & Metronidazole & $10.07 a$ & $8.78 \mathrm{~b}$ & $5.73 c$ & $8.14 b$ \\
\hline Tammuz-2 & & $10.14 a$ & $10.13 a$ & $7.79 b$ & $9.35 a$ \\
\hline Adana-99 & & $10.07 a$ & $9.55 a$ & $7.71 b$ & $9.11 \mathrm{a}$ \\
\hline Paracetamol & & $10.11 \mathrm{a}$ & $10.47 a$ & $9.74 a b$ & $10.10 a$ \\
\hline Metronidazole & & $10.11 \mathrm{a}$ & $9.21 b$ & $5.75 c$ & $8.36 b$ \\
\hline Means & & $10.11 a$ & $9.84 a$ & $7.75 b$ & \\
\hline
\end{tabular}

* Means of each factor or their interaction shared similar letters are not significantly different at $5 \%$ level according to Duncan test.

Regarding the longest seedling rootlet length for eight days old seedlings, the results displayed in table (4), showed no significant differences between varieties while drastic reduction in longest rootlet was clear for metronidazole treatment (4.78). Both concentrations 500 and $1000 \mathrm{ppm}$ influenced at the same extent $(5.54$ and 5.47, respectively in comparison to the control 10.59. All interactions were significantly influenced this trait, the most deleterious effect was noticed for both varieties with metronidazole with both concentrations 500 and 1000ppm. Such retardation in wheat plumule and in wheat rootlets have been reported by Khalaf, 1989, with the systemic fungicidal seed dressing Baytan (triadimenol fuberidazol and Sibutol(bitertanol fuberidazol), the interpretation was that as resemble the effect of the growth regulator paclobutrazol and kinetin, respectively. 
Table (4): Influence of aqueous medicinal tablets of paracetamol and metronidazole on longest rootlet $(\mathrm{cm})$ of two bread wheat varieties.

\begin{tabular}{|c|c|c|c|c|c|}
\hline \multirow[t]{2}{*}{ Varieties } & \multirow{2}{*}{$\begin{array}{l}\text { Medicinal } \\
\text { tablets }\end{array}$} & \multicolumn{3}{|c|}{ Concentrations } & \multirow[t]{2}{*}{ Means } \\
\hline & & 0.00 & 500 ppm & 1000 ppm & \\
\hline \multirow{3}{*}{ Tammuz-2 } & Paracetamol & $11.21 \mathrm{a}$ & $9.04 b$ & $8.71 b$ & $9.65 a$ \\
\hline & Metronidazole & $11.21 \mathrm{a}$ & $1.99 c$ & $1.47 c$ & $4.89 \mathrm{~b}$ \\
\hline & Paracetamol & $9.97 a b$ & $8.86 \mathrm{~b}$ & 9.90ab & $9.57 \mathrm{a}$ \\
\hline Adana-99 & Metronidazole & $9.97 a b$ & $2.25 c$ & $1.81 \mathrm{c}$ & $4.68 \mathrm{~b}$ \\
\hline Tammuz-2 & & $11.21 \mathrm{a}$ & $5.52 b$ & $5.09 \mathrm{~b}$ & $7.27 \mathrm{a}$ \\
\hline Adana-99 & & $9.97 a$ & $5.56 \mathrm{~b}$ & $5.85 b$ & $7.12 \mathrm{a}$ \\
\hline Paracetamol & & $10.59 a$ & $8.95 b$ & $9.30 \mathrm{~b}$ & $9.61 \mathrm{a}$ \\
\hline Metronidazole & & $10.59 a$ & $2.12 \mathrm{c}$ & $1.64 \mathrm{c}$ & $4.78 b$ \\
\hline Means & & $10.59 a$ & $5.54 b$ & $5.47 \mathrm{~b}$ & \\
\hline
\end{tabular}

* Means of each factor or their interaction shared similar letters are not significantly different at $5 \%$ level according to Duncan test.

The number of rootlets per seedling displayed in table (5), showed significant differences between wheat varieties; which were 5.24 and 4.95, for Tammuz-2 and Adana-99, respectively. Concerning drugs effect, paracetamol was higher than metronidazole as this chemical retarded root growth (table 4). The higher drugs concentration $1000 \mathrm{ppm}$ only significantly reduced this trait.

Treatments were all significantly effect on this trait, the sever reduction was recorded for Tammuz-2 (4.35) with metronidazole with $1000 \mathrm{ppm}$. in comparison to the highest value (5.65) for Tammuz-2 with control (water).

Table (5): Influence of aqueous medicinal tablets of paracetamol and metronidazole on number of rootlet of two bread wheat varieties.

\begin{tabular}{|c|c|c|c|c|c|}
\hline \multirow[t]{2}{*}{ Varieties } & \multirow{2}{*}{$\begin{array}{c}\text { Medicinal } \\
\text { tablets }\end{array}$} & \multicolumn{3}{|c|}{ Concentrations } & \multirow[t]{2}{*}{ Means } \\
\hline & & $0.00 \mathrm{ppm}$ & 500 ppm & 1000 ppm & \\
\hline \multirow{3}{*}{ Tammuz-2 } & Paracetamol & $5.65 a$ & $5.27 \mathrm{~b}$ & $5.37 b$ & $5.43 a$ \\
\hline & Metronidazole & $5.65 a$ & $5.17 \mathrm{bc}$ & $4.35 \mathrm{e}$ & $5.05 b$ \\
\hline & Paracetamol & $4.75 d$ & $5.20 b$ & $4.92 \mathrm{~cd}$ & $4.95 b$ \\
\hline Adana-99 & Metronidazole & $4.75 d$ & $5.30 \mathrm{~b}$ & $4.82 d$ & $4.95 b$ \\
\hline Tammuz-2 & & $5.65 a$ & $5.22 b$ & $4.86 c$ & $5.24 a$ \\
\hline Adana-99 & & $5.25 b$ & $4.75 c$ & $4.87 c$ & $4.95 b$ \\
\hline Paracetamol & & $5.20 \mathrm{a}$ & $5.23 a$ & $5.15 a$ & $5.19 a$ \\
\hline Metronidazole & & $5.20 \mathrm{a}$ & $5.23 a$ & $4.58 \mathrm{~b}$ & $5.00 \mathrm{~b}$ \\
\hline Means & & $5.26 a$ & $5.17 \mathrm{a}$ & $4.86 \mathrm{~b}$ & \\
\hline
\end{tabular}

* Means of each factor or their interaction shared similar letters are not significantly different at $5 \%$ level according to Duncan test.

Seedlings fresh weight was significantly influenced by wheat varieties; Tammuz-2 surpassed Adana-99, (2.148 and 1.973 respectively). The effect of drugs resembled number of rootlets as it was reduced by metronidazole, whereas the highest concentration $1000 \mathrm{ppm}$ only significantly reduced seedlings fresh weight. All treatment interactions were significantly effected on this trait, the combination of Adana-99 with metronidazole at $1000 \mathrm{ppm}$ recorded the lowest value 1.521 with comparison to the highest once Tammuz-2 with water.

The differences between wheat varieties can be interpreted by their genetic makeup variance, while the effect of drugs on seedlings growth retardation could be attributed to their growth regulatory behavior particularly metronidazole which belongs to azole compounds such as paclobutrazol which have 
been used commonly as plants growth regulator by numerous investigators (Berova, et al., 2002). Who found significant reduction in seedlings height and fresh weight of shoots and an increase in root production due to paclobutrazol growth regulator. These results contradict those of Sharma and Malan, 2017, who found that the values of germination\%, vigor index, root length, fresh weight and dry weight of Vigna radiata (Green Gram) was more at $80 \%$ concentration of paracetamol.

Table (6): Influence of aqueous medicinal tablets of paracetamol and metronidazole on seedling fresh weight $(\mathrm{g})$ of two bread wheat varieties.

\begin{tabular}{|c|c|c|c|c|c|}
\hline \multirow[t]{2}{*}{ Varieties } & \multirow{2}{*}{$\begin{array}{l}\text { Medicinal } \\
\text { tablets }\end{array}$} & \multicolumn{3}{|c|}{ Concentrations } & \multirow[t]{2}{*}{ Means } \\
\hline & & $0.00 \mathrm{ppm}$ & 500 ppm & 1000 ppm & \\
\hline \multirow{3}{*}{ Tammuz-2 } & Paracetamol & $2.387 a$ & $2.383 a$ & $2.297 a b$ & $2.356 a$ \\
\hline & Metronidazole & $2.387 a$ & $1.909 c$ & $1.526 \mathrm{~d}$ & $1.941 b c$ \\
\hline & Paracetamol & $2.137 b$ & $2.164 b$ & $2.118 b$ & $2.139 b$ \\
\hline Adana-99 & Metronidazole & $2.137 \mathrm{~b}$ & $1.761 \mathrm{c}$ & $1.521 d$ & $1.806 \mathrm{c}$ \\
\hline Tammuz-2 & & $2.387 a$ & $2.146 a b$ & $1.912 \mathrm{bc}$ & $2.148 a$ \\
\hline Adana-99 & & $2.137 a b$ & $1.962 \mathrm{bc}$ & $1.819 c$ & $1.973 b$ \\
\hline Paracetamol & & $2.262 \mathrm{a}$ & $2.273 a$ & $2.208 a$ & $2.247 a$ \\
\hline Metronidazole & & $2.262 a$ & $1.835 b$ & $1.523 \mathrm{c}$ & $1.873 b$ \\
\hline Means & & $2.262 \mathrm{a}$ & $2.054 b$ & $1.865 c$ & \\
\hline
\end{tabular}

* Means of each factor or their interaction shared similar letters are not significantly different at 5\% level according to Duncan test.

The seedlings dry weight were significantly affected by wheat varieties, drugs, and concentrations, as well all interactions table (7), although there were inconsistency in the value of this trait, but was obvious that metronidazole particularly with high concentration which caused drastic suppression in rootlets growth, resulted in higher dry weight, the interpretation was that the seeds were not removed from the seedlings and were contribute in whole seedlings weight and could be due to the better food reserved in the onion seeds germination of onion treated seeds with paclobutrazol. (Kumar, et al., 2016). Similarly Attrazadeh, et al., 2018, have reported to a significant increase in shoot's dry weight of soybean seedlings treated with $100 \mu \mathrm{M}$ paclobutrazol compared to non-treated in eight hours of cold tension.

However, the results are in agreement with those of Jjemba, 2002, who found that the growth of soybean plants was affected by increasing concentrations of the chloroquine, metronidazole, and quinacrine dihydrochloride. The plants were particularly sensitive to low concentrations of metronidazole. Also it was in harmony with those of An J1, et al., 2009. Who reported that wheat shoots and root elongation decreased significantly with an increase in the concentration of paracetamol. Wheat roots were the most sensitive sites of the plants to paracetamol. However, the activity of peroxidase in wheat roots decreased significantly after the 14-day exposure, which indicated the antioxidative defensive system in wheat roots was damaged by paracetamol.

Similar results were noticed by Viccini, et al. 1977. Who reported that metronidazole at a high concentration $(1,250 \mathrm{mg} / 50 \mathrm{~mL})$ behaved as a radiosensibilizer in the presence of radiation. Even at a low concentration (250 $\mathrm{mg} / 50 \mathrm{~mL} ; 750 \mathrm{mg} / 50 \mathrm{~mL}$ ) and in the absence of radiation, metronidazole behaved as toxic substance.

Yakubu, 2017. Stated that drug tablet metronidazole is toxic to soybean plants (Glycine max) based on dose-response criterion. There is a need to enforce treatment of pharmaceutical wastewater effluent by Pharmaceutical Manufacturing Companies before discharge into the environment.

It was worth to mention that paracetamol treated seeds colored dark black, such coloration was attributed to that reported by Minz, et al., 2018, who illustrated that the enzyme tyrosinase 
present in the outer layers of wheat grain react with the phenol and oxidize it to quinines which are subsequently converted to dark colored melanin's by polymerization and interaction with protein. Intensity of color depends on the amount of tyrosinase enzyme. Tyrosinase activity is found to be an inherited characteristic for phenol test. This test was well known in identifying mixture of wheat varieties. It could be substituted by phenol reaction test as phenol is caustic and with a foul odor.

Table (7): Influence of aqueous medicinal tablets of paracetamol and metronidazole on seedling dry weight $(\mathrm{g})$ of two bread wheat varieties.

\begin{tabular}{|c|c|c|c|c|c|}
\hline \multirow[t]{2}{*}{ Varieties } & \multirow{2}{*}{$\begin{array}{l}\text { Medicinal } \\
\text { tablets }\end{array}$} & \multicolumn{3}{|c|}{ Concentrations } & \multirow[t]{2}{*}{ Means } \\
\hline & & 0.00 ppm & 500 ppm & 1000 ppm & \\
\hline \multirow{3}{*}{ Tammuz-2 } & Paracetamol & $0.407 c$ & $0.415 b c$ & $0.421 b c$ & $0.414 b$ \\
\hline & Metronidazole & $0.407 c$ & $0.434 b$ & $0.427 \mathrm{bc}$ & $0.423 a b$ \\
\hline & Paracetamol & $0.423 \mathrm{bc}$ & $0.433 b$ & $0.423 b c$ & $0.426 a b$ \\
\hline Adana-99 & Metronidazole & $0.423 \mathrm{bc}$ & $0.430 \mathrm{bc}$ & $0.456 a$ & $0.436 a$ \\
\hline Tammuz-2 & & $0.407 \mathrm{~b}$ & $0.425 a$ & $0.424 a$ & $0.419 b$ \\
\hline Adana-99 & & $0.423 a$ & $0.431 a$ & $0.440 a$ & $0.431 \mathrm{a}$ \\
\hline Paracetamol & & $0.415 b$ & $0.424 b$ & $0.422 b$ & $0.420 b$ \\
\hline Metronidazole & & $0.415 b$ & $0.432 \mathrm{ab}$ & $0.441 \mathrm{a}$ & $0.429 a$ \\
\hline Means & & $0.415 b$ & $0.428 \mathrm{a}$ & $0.432 a$ & \\
\hline
\end{tabular}

* Means of each factor or their interaction shared similar letters are not significantly different at $5 \%$ level according to Duncan test.

\section{REFERENCES}

An J1, Zhou Q, Sun F, Zhang L. (2009). Ecotoxicological effects of paracetamol on seed germination and seedling development of wheat (Triticum aestivum L.). J Hazard Mater. 2009 Sep 30;169(1-3):751-7.

Attarzadeh,M., Balouchi,H., Baziar, M.R. (2018).Effects of paclobutrazol's pretreatment on cold tolerance induction in soybean seedling (Glycine max.L.).Italian Journal of Agronomy, 13:1034.

Berova, M., Zlatev, $Z$ and Stoeva., N. (2002). Effect of paclobutrazol on wheat seedlings under low temperature stress. BULG.J.PLANT PHYSIOL.28(1-2),75-84.

Bulbul, E.N., and Ozhan, G., (2012).Cytotoxic effects of triazole fungicides. Istanbul Ecz.Fak.Derg,/J. Fac. Pharm.42(1):23-31.

Gortz, A., Oerke, E.C. Thomas Puhl, Th., and Steiner,U. (2008). Effect of environmental conditions on plant growth regulator activity of fungicidal seed treatments of barley. Journal of Applied Botany and Food Quality $82,60-68$.

Hof, K., Grosse., and Daussantz, J., (1987).Simulation of growth and \& -amylase formation by the fungicide Sibutol in developing wheat seedlings. Journal of plant physiology, 131(S 1-2):163-169.

ISTA, (2013). Rules of the International Seed Testing Association.Zurichstr,50, CH-8303 Bassersdorf, Switzerland.

Jjemba, P.K., (2002). The effect of chloroquine, quinacrine, and metronidazole on both soybean plants and soil microbiota. Chemosphere.46(7):1019-1025.

Jung, J., Rentenzea, C., and Rademacher, W. (1985). Plant growth regulation with triazoles of the dioxanyl type. Journal of plant growth regulation.4:181.

Khalaf, A.S., (1989).Study of wheat ( $T$.aestivum L.) germination and seedling performance resulting from some chemical treatments. Ph.D. thesis- Dept. of Agricultural Botany, University College Dublin, The National University of Ireland.

Khattar, V.S. and Hathiram, B.T. (2009). Medical therapy for fungal rhinosinusitis. Otorhinolaryngology Clinics: An International Journal,1(1):63-67.

Koller, W. (1987). Plant growth regulator activities of stereochemical isomers of triadimenol. Physiol. Plant. 71: 309-315.

Kumar, S., Tomar, B.S., Arora, A. Saharawat,Y.S., Kumar, A., and Sharma, 
R. (2016). Influence of plant growth retardants on rowth, seed yield and quality in onion (Allium cepa) cv.Pusa Riddhi. Indian Journal of Agricultural Sciences,86 (11): 1413-1417.

Kumar, S., Virndra, K., Prem, N., Ramesh, S. and Biswas, S.K. 2019. Effect of seed treatment of fungicides and biocides against spot blotch of wheat caused by Bipolaris sorokiniana. Int. J. Curr. Microbiol. App. Sci. 8(1):1223-1229.

Lurssen, K., (1987). The use of inhibitors of gibberellin and sterol biosynthesis to probe hormone action. In Hormon action in plant development a critical appraisal (ed.Hoad, G.V., et al., 1987), Butterworth \& Co. Publishers, Ltd.

Lurssen., K. and Reiser W. (1987). Triapenthenol - a new plant growth regulator. Pesticide Science .19(2):153 - 164.

Minz, M.G., Agrawal, A.P., Parihar, R., and Gupta, V.K. (2018). Identification of good Chapati quality wheat cultivar in Chhattisgarh through phenol test. Journal of Pharmacognosy and Phytochemistry. 7(6): 1865-1866.

Montfort,F., Klepper, B.L., and Smiley, R.W., (1996).Effects of two triazole seed treatments, triticonazole and triadimenol, on growth and development of wheat.Pestic.Sci.46.315-322.

SAS, (2003). Program version,9.1.

Sharma, H. R., and Malan, A. (2017). Effect of paracetamol and ibuprofen on morphological parameters and chlorophyll content of Vigna radiata (Green Gram). Environ. We Int. J. Sci. Tech.12:99-108.

Smiley, R.W., Patterson, L., and Rhinhart, K. E.L., (1996). Fungicide seed treatment effects on emergence of deeply planted winter wheat. J. Prod. Agric., 9(4):564-570.

Soumya, P.R., Pramod K., and Madan, P. (2017). Paclobutrazol: a novel plant growth regulator and multi-strees ameliorant.Ind $\mathrm{J}$ Plant Physiol 22(3):267-278.

Viccini, L.F., Saraiva, L.S., Filho, J.A., Cruz, C.D. and Andrade,R.A.(1997). The radiosensitizing effect of metronidazole in maize. Bragantia, 56 (2).

Yakubu, O, H, (2017). Pharmaceutical wastewater effluent source of contaminants of emerging concern: Phytotoxicity of metronidazole to soybean (Glycine max). Toxics 2017, 5, 10. 


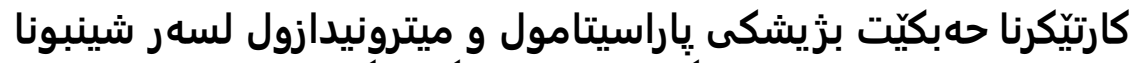

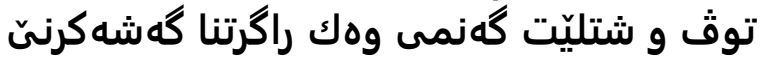

يوخته

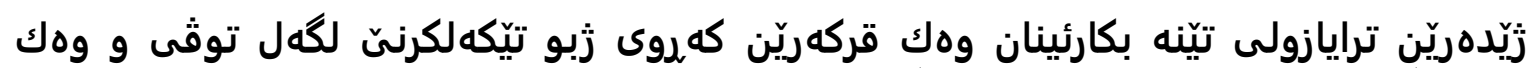

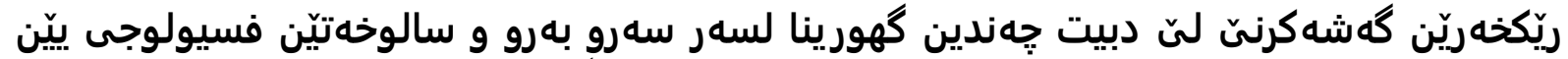

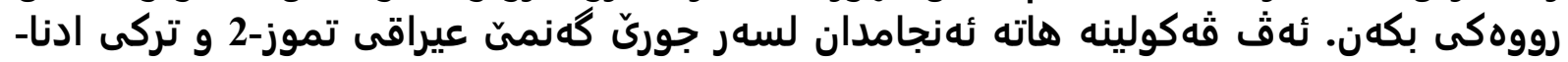

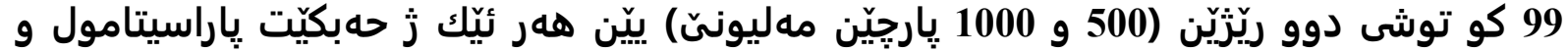

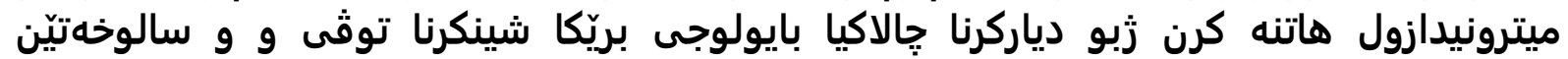

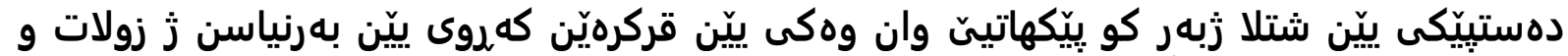

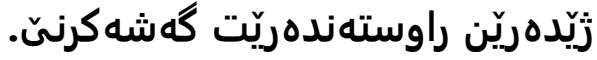

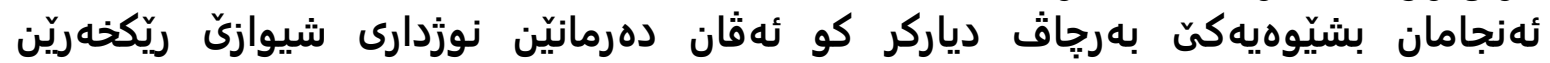

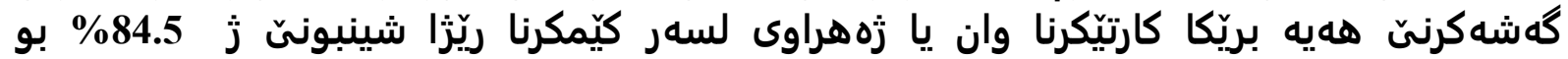

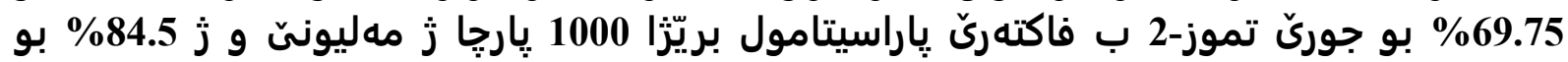

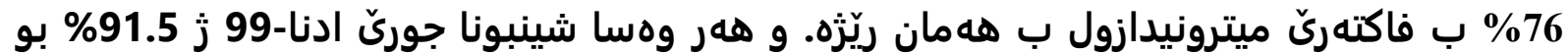

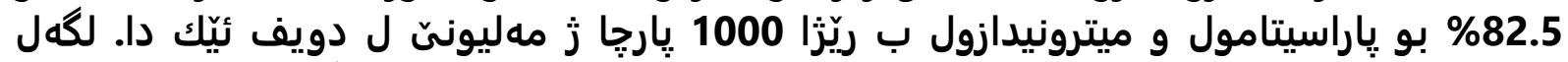

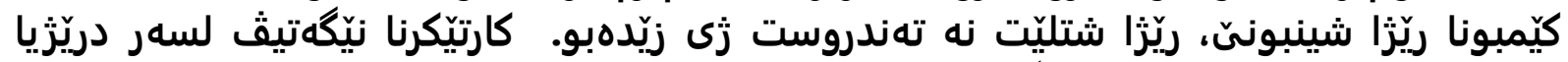

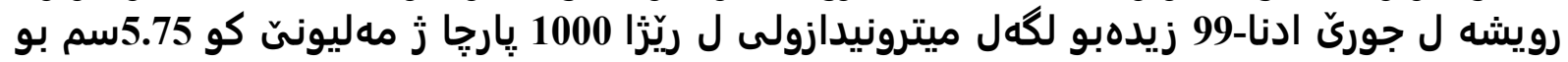

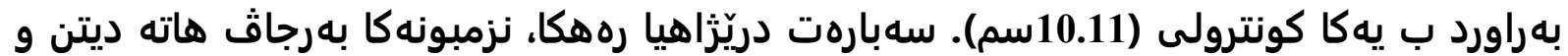

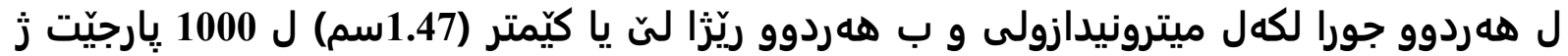

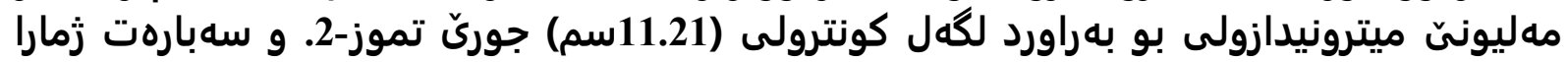

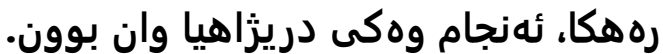

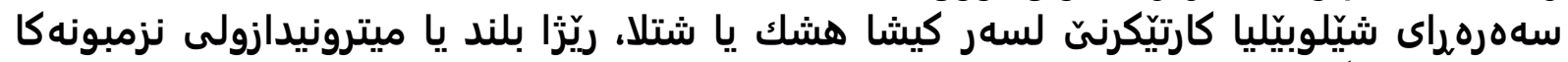

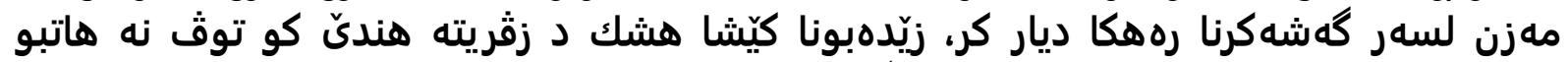

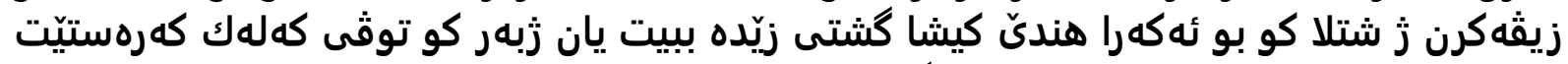

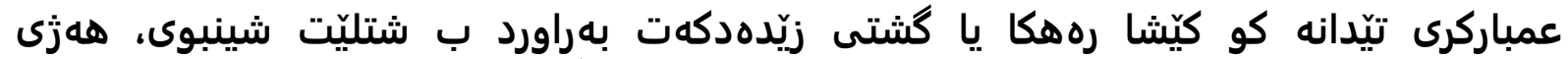

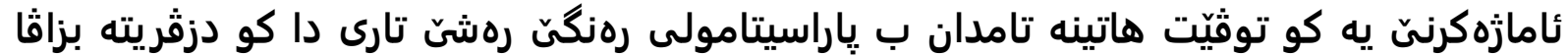

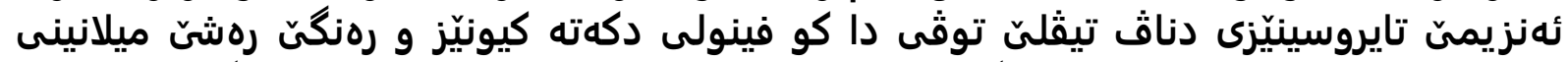

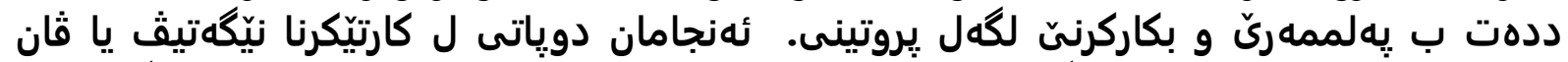

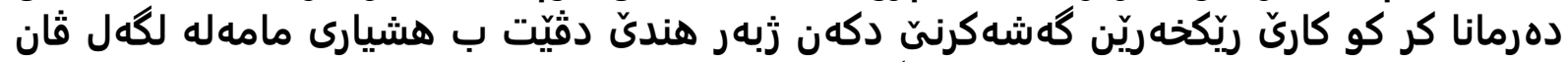

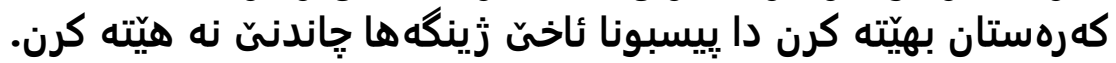

تاثير الاقراص الطبية باراسيتامول و ميترونيدازول في انبات بذور الحنطة ونمو الباذرات كمثبطات النمو 
عادة تستخدم مشتقات الترايازول كمبيدات فطرية لتعفير البذور او كمنظمات نمو ولكنها قد

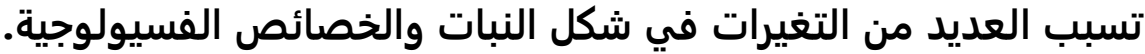

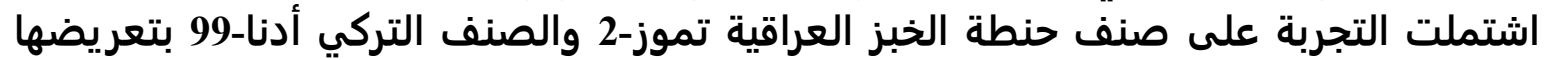

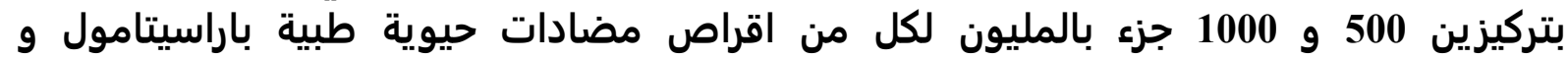

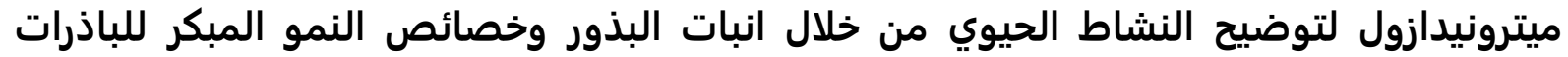

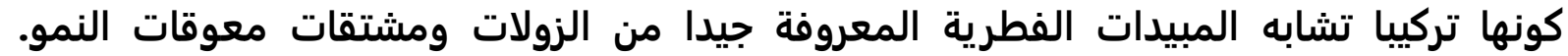

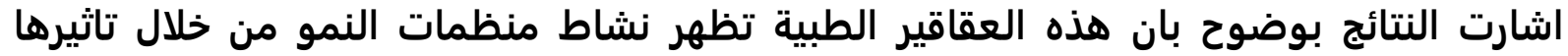

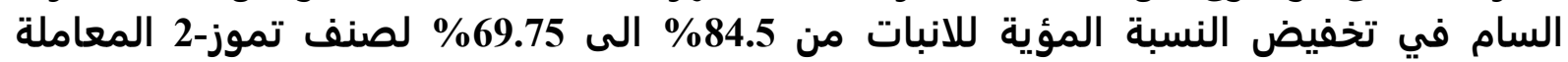
بالباراسيتامول بتركيز 1000 جزء من المليون، ومن 84.5\% الفيات

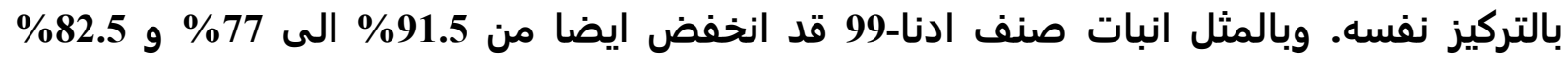

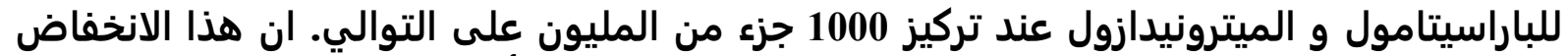

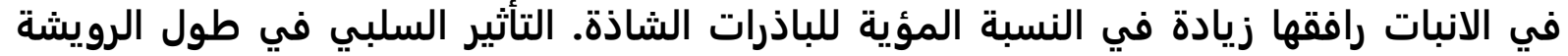

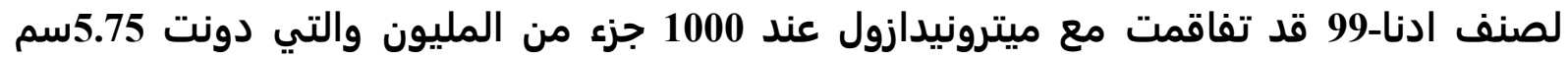

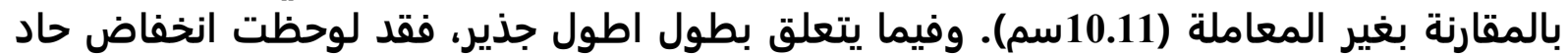

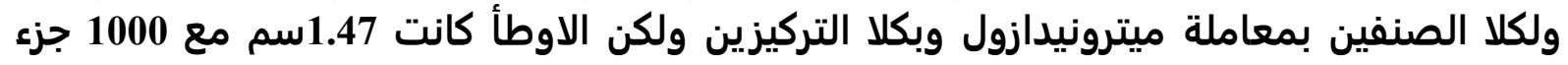

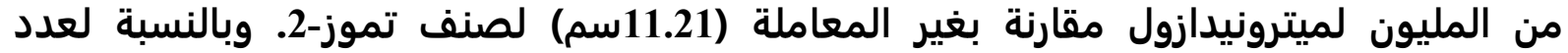

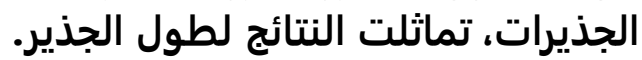

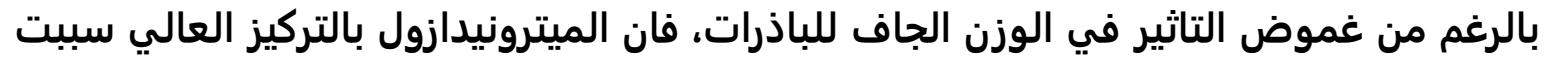

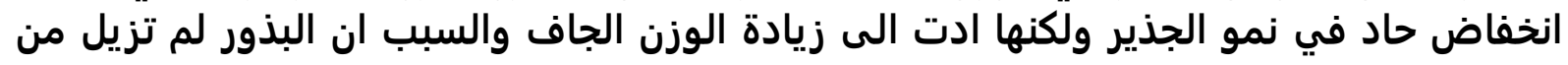

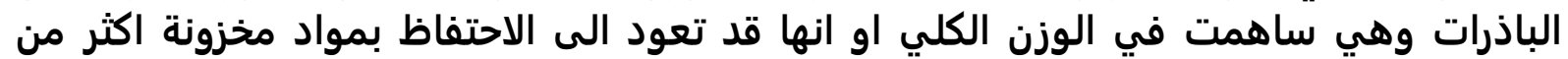

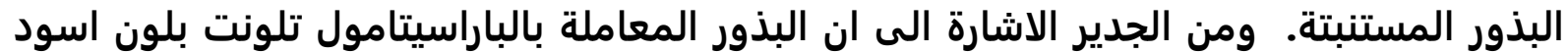

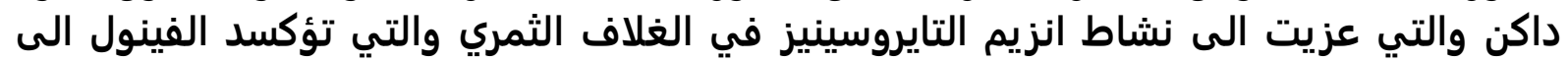

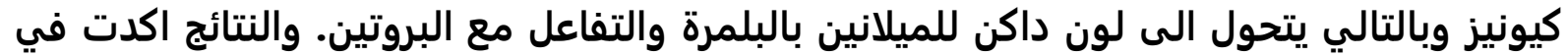

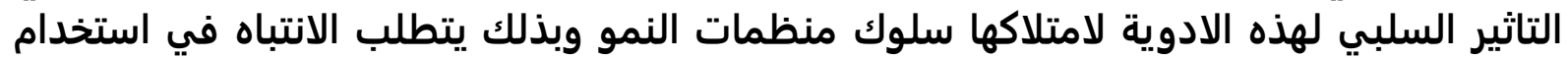

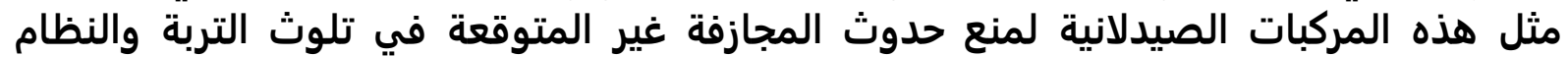
البيئي الزراعي. 